REPORT

\title{
Dendritic cells: potential triggers of autoimmunity and targets for therapy
}

\section{J A Hardin}

D endritic cells (DCs) are often referred to as the body's sentinels, constantly guarding against pathogens. ${ }^{1-3}$ In this role they are the antigen presenting cell that primes naive $\mathrm{T}$ cells in vivo. ${ }^{4}$ DCs also help maintain tolerance to "self" substances through multiple mechanisms that include $\mathrm{T}$ cell deletion and anergy as well as the generation of regulatory T cells. ${ }^{5-7}$ This dual role in regulating both immune responses and immune tolerance suggests that DCs are likely to have a role in autoimmune diseases such as lupus. The possibilities include presentation of "self" antigens as immunogens, a failure to delete autoreactive $\mathrm{T}$ cells, overproduction of inflammatory cytokines, and inadequate induction of regulatory $\mathrm{T}$ cells. As noted below, insights into these pathogenetic mechanisms in lupus are beginning to emerge. It is also clear that at least some of these activities of DCs can be manipulated through pharmacological agents. ${ }^{8}$ ?

It has been thought for a long time that regulatory $\mathrm{T}$ cells are related to the pathogenesis of lupus. ${ }^{10}{ }^{11}$ Now, at the forefront of this consideration is the possibility that DCs play a critical role in balancing the array of autoreactive $\mathrm{T}$ cells with a corresponding set of regulatory T cells. ${ }^{12}$ It is clear that immature DCs induce deletional tolerance of autoreactive $\mathrm{T}$ cells in the periphery. ${ }^{13-15}$ However, the original concept that immature DCs are responsible for tolerance and mature DCs induce immune responses has given way to a more complex scenario in which DCs in different states of maturation are able to induce $\mathrm{CD} 4+\mathrm{CD} 25+$ regulatory $\mathrm{T}$ cells. ${ }^{16}{ }^{17}$ In this paper, my aim is to consider the possibility that the maturation of DCs might be manipulated in such a way as to either enhance regulatory $\mathrm{T}$ cell generation or diminish priming of autoreactive effector T cells in patients with lupus.

\section{SUBSETS}

As illustrated in fig 1 and reviewed in reference 20, DCs derive from two sources, stem cells in the bone marrow and precursor cells found in the circulation. It is likely that there are multiple subtypes-differing in molecular characteristics and functional properties-within each of the four major groups of DCs shown here. It remains unclear to what extent these subspecies arise through differences in lineage or in response to environmental stimuli such as cytokines. ${ }^{20-23}$

Langerhans' cells are characterised by the presence of Birbeck's granules as well as expression of langerin. Since these cells reside within the epidermis they are poised to have the first interaction with an invading pathogen. ${ }^{24} 25$ Langerhans' cells have several specialised properties. Firstly, langerin and its associated Birbeck's granules are thought to represent an antigen uptake system unique to these cells. ${ }^{26}$ Secondly, they are thought to be uniquely designed to transport antigens from the dermis to regional lymph nodes ${ }^{27}$ and they may be more focused on generating exclusively $\mathrm{T}$ helper (Th) 1 responses because of their lack of interleukin (IL)-10 secretion. ${ }^{28}$ Finally, these cells contribute to, but are not essential for, contact hypersensitivity. ${ }^{29}$ It is possible these cells have a unique role in autoimmune responses to the Ro antigen. ${ }^{30} 31$

Interstitial DCs are found in the dermis and throughout the body's tissues. Veils characterise these cells morphologically or dendrites and they are often identified by the presence of high levels of the myeloid cell marker CDIlc. Much of what we know about these cells in humans is based on studies of cells derived ex vivo from blood monocytes or from CD34+ stem cells grown in the presence of granulocyte macrophagecolony stimulating factor (GM-CSF) and IL-4. ${ }^{7}$ These cells are able to secrete large quantities of IL-12 and thus can drive T cells towards Th 1 responses. ${ }^{28}$ Interstitial DCs are derived from a CD34+CLA- stem cell in the bone marrow. ${ }^{20}$ Monocytes can be induced to differentiate into similar cells, ${ }^{32}$ and may represent a reservoir for expansion of interstitial DCs in emergencies. Interstitial DCs within the circulation can be identified as HLA-DR+, lin-, CDllc+ cells. ${ }^{33}{ }^{34}$ Such cells are likely to represent multiple subtypes of DCs in unknown states of maturation, perhaps comprising some combination of interstitial DCs that have migrated into the blood and monocyte derived DCs that have yet to egress from the circulation. In normal individuals, these cells represent about $0.3 \%$ of the peripheral blood mononuclear cells. In lupus, their numbers are variable but tend to be reduced. ${ }^{35}$

Interstitial DCs exist mainly in an immature form during the steady state. A variety of stimuli including signals delivered through toll-like receptors (TLRs), CD40, and tumour necrosis factor receptors as well as stimulation with type 1 interferons (IFNs) trigger their maturation, a process that takes place over a matter of hours. The cells cease uptake of extracellular material, digest the contents of their lysosomal vacuoles, and process antigens into peptides associated with major histocompatibility complex (MHC) molecules that translocate to the cell surface. Simultaneously the maturing cells upregulate their expression of costimulatory molecules such as CD80 and CD86. Somewhere between the immature "tolerogenic" state and the mature "immunogenic" a form of DCs appear to exist with optimal ability to induce antigen specific regulatory $\mathrm{T}$ cells. A potential new approach in lupus is to find a way to enhance the population of DCs that is most effective at induction of regulatory $\mathrm{T}$ cells. A potential strategy for this goal is application of agents that modulate maturation of DCs.

Plasmacytoid DCs are also derived from specialised precursors within the circulation. ${ }^{36}$ These precursors respond to bacteria and viruses with production of enormous quantities of type I IFNs and hence are often referred to as the IFN producing cells (IPCs). These cells express TLR9, that is responsive to bacterial DNA and oligonucleotides bearing certain CpG motifs, and TLR7 for which the natural ligand is unknown (although a number of synthetic products in

Abbreviations: DC, dendritic cell; GM-CSF, granulocyte macrophagecolony stimulating factor; IFN, interferon; IL, interleukin; TLR, toll-like receptor 


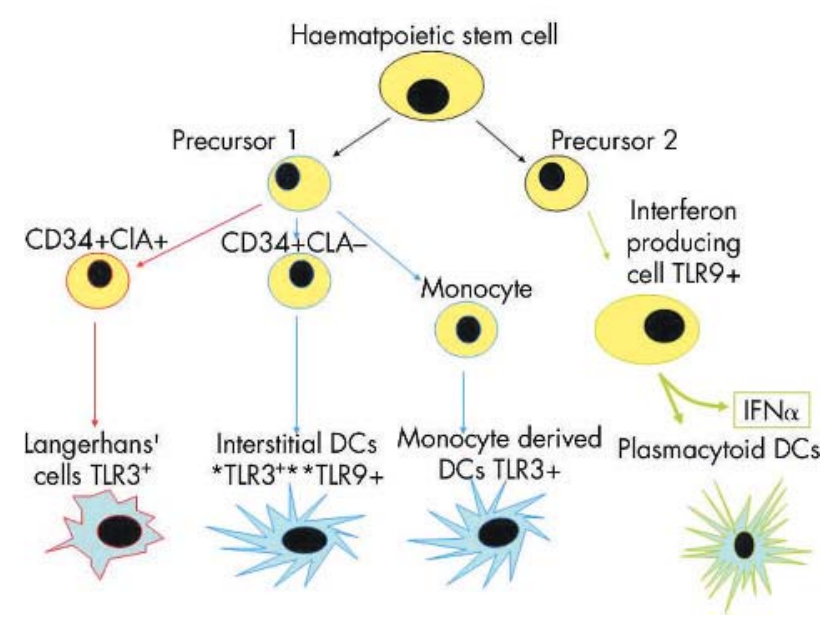

Figure 1 Dendritic cell (DC) lineages. DCs are derived from bone marrow stem cell and from more differentiated cells in the periphery, monocytes that give rise to cells that may be equivalent to interstitial DCs and an interferon (IFN) producing cell that differentiates into a plasmacytoid DC also known as PDC2.TLR, toll-like receptor. *Identified in immature DCs from peripherial blood ${ }^{18} ;{ }^{* *}$ Identified in mouse splenic DCs. ${ }^{19}$

therapeutic use, including imiquimod, activate cells via this receptor). Although the range of ways in which plasmacytoid cells sense viruses and bacteria remains incompletely understood, we do know that when stimulated these cells secrete large amounts of type I IFNs and activate a differentiation programme to become DCs that are often referred to as pDC2s. As this process takes place, the pDC2s rapidly egress from the circulation and probably move to sites of inflammation. These cells are thought to have unique roles in regulating immune responses. The plasmacytoid DC precursors represent about $0.5 \%$ of the circulating peripheral blood mononuclear cells. ${ }^{35}$

\section{DCs AND THE PATHOGENESIS OF LUPUS}

Lupus is a highly variable disease that may involve almost any organ in the body. It is clear from both animal and human studies that a large number of genes regulating many different aspects of the immune system are involved. It seems likely that the relevant alleles acting alone in humans cause only minor perturbations in specific $\mathrm{T}$ cell and $\mathrm{B}$ cell regulatory mechanisms, autoantigen clearance, apoptosis, or antigen presentation whereas collectively they come together in unique combinations in individual patients to create an immune system that can be triggered by some environmental stimulus to respond to "self"-antigens. Most likely this autoimmune response is one that is self-sustaining even after the initial trigger is no longer present. In this regard, it is important to note that this response almost always includes autoimmunity to chromatin-that is nucleosomes, histones, and DNA. ${ }^{37}$ Why the response so regularly involves chromatin remains unclear. One possibility is that the durability of chromatin in the extracellular environment provides for a particularly effective ongoing antigen stimulus that may augment responses to other nuclear antigens.

Many of our observations of lupus can be rationalised through a consideration of the biology of DCs. Plasmacytoid DCs are consistently reduced numerically in this disease. ${ }^{35}$ Myeloid DCs also appear to be reduced but less consistently and less profoundly. Presumably the circulating DCs have become activated and migrated into peripheral lymphoid tissues and sites of inflammation. ${ }^{35}{ }^{38}$ In fact, mature plasmacytoid DCs have been observed to accumulate in lupus skin lesions. ${ }^{31}$ Administration of corticosteroids consistently decreases the number of circulating DCs, but in lupus the decreases are observed before the application of this agent.

Paradoxically, considering the reduction in circulating myeloid DCs in lupus, sera from patients with lupus promote differentiation of monocytes into DCs. The stimulus is IFNa that is produced in lupus patients at abnormally high levels. In some patients, elevated levels of type I IFNs are detectable with enzyme-linked immunosorbent assays. In many more patients gene expression profiles demonstrate that type I IFN responsive genes are activated abnormally. ${ }^{39-41}$ This interferon signature is especially prominent in paediatric lupus where the disease is likely to be most severe. These findings indicate that production of type I IFNs is augmented in patients with lupus during periods of active disease. These IFNs are derived from circulating plasmacytoid DC precursors that are triggered by immune complexes containing nucleic acids. ${ }^{42-46}$ As illustrated in fig 2, in individuals with a permissive genetic background an environmental stimulus for release of these IFNs could set in motion a self-sustaining response that is expressed ultimately as lupus.

Several observations support the idea that chronic stimulation of DC maturation results in a lupus phenotype. For example, overexpression of CD40L in the basal layers of the epidermis accelerates maturation and migration of DCs to regional lymph nodes in mice. ${ }^{47}$ These animals exhibit dermatitis caused by cellular autoimmune responses to skin antigens as well as autoantibodies to nuclear antigens including DNA. This model demonstrates that chronic DC activation leads to autoimmunity corresponding to antigens that reside where the initial activation of the DCs takes place. More directly, it has been noted recently that vaccinations with mature DCs that have ingested apoptotic cells in culture induces antinuclear antibodies in normal mice and accelerates autoimmunity in lupus prone mice. ${ }^{48}$ Moreover, the repeated transfer of mature bone marrow derived DCs into normal $\mathrm{C} 57 / \mathrm{Bl} 6$ mice breaks tolerance and induces the expression of anti-DNA antibodies. This effect was observed even though the DCs were not intentionally exposed to a source of apoptotic cells. ${ }^{49}$ These mice did not develop disease however, indicating that an anti-chromatin autoantibody response alone is not sufficient for tissue injury and disease

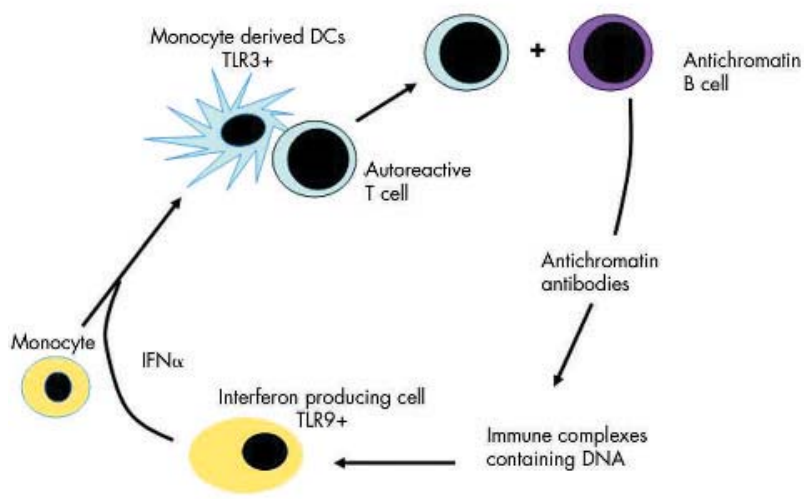

Figure 2 The interferon (IFN) cycle in lupus. IFN $\alpha$ released from plasmacytoid dendritic cell (DC) precursors drives monocyte maturation to myeloid DCs that provide T cell help for autoreactive B cells. The antigen specificity of the latter cells is unknown but theoretically could be any antigen presented by $B$ cells that produce autoantibodies. In the example shown here antichromatin B cells are depicted because their product has been shown to trigger release of IFN $\alpha$ from plasmacytoid cell precursors. TLR, toll-like receptor. 
induction. Thus, it is clear that augmented DC maturation leads to autoimmunity, that lupus blood promotes DC maturation, and that mature DCs induce autoimmune responses consistent with lupus. These considerations suggest that restraining maturation of DCs in vivo should benefit patients with lupus.

\section{PHARMACOLOGICAL MODULATION OF DCs}

As shown in table 1, a number of agents affect DCs, making it possible to alter the number of DCs, change their circulatory patterns, and influence their impact on $\mathrm{T}$ cells. To a large extent the immunosuppressive agents listed here have been in wide clinical use but with little attention to their specific impact on DCs. Corticosteroids, for example, have profound effects on these cells. They quickly suppress the number of circulating plasmacytoid DC precursors in vivo ${ }^{50}{ }^{51}$ and alter both the differentiation and maturation of DCs both in vitro and in vivo, ${ }^{52-56}$ and change the ability of these cells to respond to chemotactic stimuli. ${ }^{57}$ However, little is known of how best to apply corticosteroids to achieve a selective impact on DCs. Perhaps one of the mechanisms through which low doses or alternate day doses of corticosteroids benefit patients with lupus is through an impact on DC biology. A better understanding of how corticosteroids affect DCs, including minimal required doses and optimal dose schedules will refine their use for control of autoimmunity.

$1 \alpha, 25(\mathrm{OH})_{2}$ vitamin $\mathrm{D}_{3}$, the active form of vitamin $\mathrm{D}$, is another endogenously generated hormone that has profound effects on the immune system. Many of these effects are similar to those caused by corticosteroids. The nuclear receptor for this hormone is present in DCs as well as macrophages and T cells. ${ }^{61}$ In vitro, CD4+ T cell proliferation is suppressed. ${ }^{62}$ Monocytes have altered responses to differentiation signals such as GM-CSF and type l IFNs. The resulting DCs retain the monocyte marker CD14, fail to upregulate CDla, and retain the ability to carry out macropinocytosis. ${ }^{63}{ }^{64}$ Thus these cells have features more in keeping with immature DCs than do DCs derived from monocytes using conventional culture methods such as those based on a combination of GM-CSF and IL-4, a traditional method for inducing monocytes to differentiate into DCs. ${ }^{65} 66$ $1 \alpha, 25(\mathrm{OH})_{2}$ vitamin $\mathrm{D}_{3}$ and several analogues of this

Table 1 Pharmacological intervention in dendritic cell (DC) biology

\begin{tabular}{|c|c|c|}
\hline Agent & Biological effect & Ref \\
\hline Corticosteroids & $\begin{array}{l}\text { Suppresses number of plasmacytoid } \\
\text { DC precursors } \\
\text { Restrains monocyte differentiation } \\
\text { into DCs } \\
\text { Suppresses monocyte derived DC maturation } \\
\text { Suppresses interleukin (IL)-12 production } \\
\text { Enhances IL-10 production by DCs }\end{array}$ & 52 \\
\hline $\begin{array}{l}1,25(\mathrm{OH})_{2} \\
\text { vitamin } D_{3}\end{array}$ & $\begin{array}{l}\text { Restrains monocyte differentiation } \\
\text { into DCs } \\
\text { Suppresses monocyte derived DC maturation } \\
\text { Suppresses IL-12 production } \\
\text { Enhances IL-10 production by DCs } \\
\text { Modulates DC responses to chemotactic signals }\end{array}$ & $\begin{array}{l}9 \\
\text { Is }\end{array}$ \\
\hline Hydrochloroquine & Prevents lysosomal vacuole acidification & 58 \\
\hline Ciclosporin & Suppresses tumour necrosis factor production & 8 \\
\hline Mycophenolate & $\begin{array}{l}\text { Retards DC maturation. Reduces IL-12 } \\
\text { production }\end{array}$ & 59 \\
\hline Tick saliva & Retards Langerhans' cell migration & 60 \\
\hline
\end{tabular}

hormone have been shown to be effective in suppressing a number of autoimmune disease models such as experimental allergic encephalitis, inflammatory bowel disease, and collagen induced arthritis as well as the lupus-like autoimmune disease of MRL mice. ${ }^{6}$ In addition, $1 \alpha, 25(\mathrm{OH})_{2}$ vitamin $\mathrm{D}_{3}$ tolerises mice towards organ grafts. One of the mechanisms is generation of antigen specific regulatory $\mathrm{T}$ cells that sustain the engrafted tissue. ${ }^{67}{ }^{68}$ Vitamin $\mathrm{D}_{3}$ is limited in clinical applications because it indices hypercalcaemia when present in pharmacological concentrations. Consequently, only a topical vitamin D preparation is in clinical use for treatment of psoriasis. A number of vitamin D analogues are in development with the aim of retaining the immune modulatory effects of $1 \alpha, 25(\mathrm{OH})_{2}$ vitamin $\mathrm{D}_{3}$ while avoiding the hypercalcaemic effects.

However, use of $1 \alpha, 25(\mathrm{OH})_{2}$ vitamin $\mathrm{D}_{3}$ for treatment of lupus presents a special set of considerations. We know from epidemiological studies that patients with lupus often have vitamin D deficiency. ${ }^{69-71}$ It is likely that our advice to avoid sunlight $^{72}$ as well as drugs such as corticosteroids that impair vitamin $\mathrm{D}$ adsorption and conversion of vitamin $\mathrm{D}$ precursors to the active vitamin $\mathrm{D}_{3}$ hormone are responsible. ${ }^{73}{ }^{74}$ Therefore special attention should be paid to correcting vitamin D levels in patients with lupus. As this goal is achieved we have an opportunity to identify any beneficial effects on the immune system that are achieved in addition to those that accrue to bone health. This information will contribute to a better understanding of the potential role that vitamin $\mathrm{D}_{3}$ might play in preventing autoimmune disorders.

Among the other agents that affect DCs, hydrocholoroquine (Plaquenil) and mycophenolate are of particular interest because they are already in wide use for treatment of patients with lupus. However, little attention has been paid to how these agents affect DCs in vivo. Hydrochloroquine blocks lysosomal acidification in vitro and possibly retards presentation of "self"-antigens. ${ }^{58} 75$ Mycophenolate has been shown to retard maturation of DCs. ${ }^{59} 76$ Also, mycophenolate synergises with $1 \alpha, 25(\mathrm{OH})_{2}$ vitamin $\mathrm{D}_{3}$ to promote development of regulatory $\mathrm{T}$ cells, ${ }^{67}$ presumably through an effect on DC maturation. These observations suggest that several agents might be combined in order to achieve desired alterations in DC behaviour with minimal toxicity to patients. The ability to modulate DCs for specific purposes has been incorporated into the repertoire of human host-parasite relationships as shown by the observation that tick saliva inhibits both the derivation and function of DCs. ${ }^{60}$

\section{CONCLUSIONS}

A number of agents are already in general clinical use that can be used to modulate the biology of DCs. Vitamin D and its analogues emerge as a special consideration because of its impact on both DC phenotype and function and the high incidence of deficiency of vitamin $\mathrm{D}$ in lupus. These considerations suggest that physicians should pay increased attention to vitamin $\mathrm{D}_{3}$ levels in patients with lupus. We have an important opportunity to gain further insights into the role of vitamin D in lupus simply by assessing the impact on various parameters of the immune system as we correct deficiencies of this vitamin in our patients. In the future, vitamin D analogues that do not induce hypercalcaemia may emerge as a new class of drugs specifically designed to alter DC biology in therapeutically beneficial ways.

Competing interests: none declared

Correspondence to: Dr J A Hardin, Albert Einstein College of Medicine, 1300 Morris Park Ave, Bronx, New York 10461, USA; jhardin@aecom. yu.edu 


\section{REFERENCES}

1 Steinman RM, Adams JC, Cohn ZA. Identification of a novel cell type in peripheral lymphoid organs of mice. IV. Identification and distribution in mouse spleen. J Exp Med 1975;141:804-20.

2 Steinman RM, Bonifaz L, Fujii S, Liu K, Bonnyay D, Yamazaki S, et al. The innate functions of dendritic cells in peripheral lymphoid tissues. Adv Exp Med Biol 2005:560:83-97.

3 Kubach J, Becker C, Schmitt E, Steinbrink K, Huter E, Tuettenberg A, et al. Dendritic cells: sentinels of immunity and tolerance. Int $J$ Hemato 2005;81:197-203.

4 Inaba K, Metlay JP, Crowley MT, Steinman RM. Dendritic cells pulsed with protein antigens in vitro can prime antigen-specific, MHC-restricted T cells in situ. J Exp Med 1990;172:631-40.

5 Steinman RM, Hawiger D, Nussenzweig MC. Tolerogenic dendritic cells. Annu Rev Immunol 2003;21:685-711.

6 Steinman RM, Nussenzweig MC. Avoiding horror autotoxicus: the importance of dendritic cells in peripheral T cell tolerance. Proc Natl Acad Sci U S A 2002;99:351-8

7 Steinman RM. Some interfaces of dendritic cell biology. APMIS 2003:111:675-97.

8 Hackstein $\mathrm{H}$, Thomson AW. Dendritic cells: emerging pharmacological targets of immunosuppressive drugs. Nat Rev Immunol 2004;4:24-34

9 Adorini L. Intervention in autoimmunity: The potential of vitamin D receptor agonists. Cell Immunol 2005;233:115-24.

10 Gerber NL, Hardin JA, Chused TM, Steinberg AD. Loss with age in NZB-W mice of thymic suppressor cells in the graft-vs-host reaction. $J$ Immunol 1974;113:1618-25.

11 Hardin JA, Chused TM, Steinberg AD. Supressor cells in the graft vs host reaction. J Immunol 1973;111:650-1.

12 Wu HY, Staines NA. A deficiency of CD4+CD25+T cells permits the development of spontaneous lupus-like disease in mice, and can be reversed by induction of mucosal tolerance to histone peptide autoantigen. Lupus 2004; 13:192-200.

13 Liu K, lyoda T, Saternus M, Kimura Y, Inaba K, Steinman RM. Immune tolerance after delivery of dying cells to dendritic cells in situ. J Exp Med 2002;196:1091-7.

14 Hawiger D, Inaba K, Dorsett Y, Guo M, Mahnke K, Rivera M, et al. Dendritic cells induce peripheral T cell unresponsiveness under steady state conditions in vivo. J Exp Med 2001;194:769-79.

15 Bonifaz L, Bonnyay D, Mahnke K, Rivera M, Nussenzweig MC, Steinman RM Efficient targeting of protein antigen to the dendritic cell receptor DEC-205 in the steady state leads to antigen presentation on major histocompatibility complex class I products and peripheral CD8+ T cell tolerance. J Exp Med 2002;196:1627-38.

16 Yamazaki S, lyoda T, Tarbell K, Olson K, Velinzon K, Inaba K, Steinman RM Direct expansion of functional CD25+ CD4+ regulatory T cells by antigen processing dendritic cells. J Exp Med 2003;198:235-47.

17 Tarbell KV, Yamazaki S, Olson K, Toy P, Steinman RM. CD25+ CD4+ T cells, expanded with dendritic cells presenting a single autoantigenic peptide, suppress autoimmune diabetes. J Exp Med 2004;199:1467-77

18 Kadowaki N, Ho S, Antonenko S, Malefyt RW, Kastelein RA, Bazan F, et al. Subsets of human dendritic cell precursors express different toll-like receptors and respond to different microbial antigens. J Exp Med 2001;194:863-9.

19 Mitsui H, Watanabe T, Saeki H, Mori K, Fujita H, Tada Y, et al. Differential expression and function of Toll-like receptors in Langerhans cells: comparison with splenic dendritic cells. J Invest Dermatol 2004;122:95-102.

20 Liu YJ. Dendritic cell subsets and lineages, and their functions in innate and adaptive immunity. Cell 2001;106:259-62.

21 Ardavin C. Origin, precursors and differentiation of mouse dendritic cells. Nat Rev Immunol 2003;3:582-90.

22 Shortman K, Liu YJ. Mouse and human dendritic cell subtypes. Nat Rev Immunol 2002;2:151-61.

23 Liu YJ, Kanzler H, Soumelis V, Gilliet M. Dendritic cell lineage, plasticity and cross-regulation. Nat Immunol 2001;2:585-9.

24 Merad M, Manz MG, Karsunky H, Wagers A, Peters W, Charo I, et al. Langerhans cells renew in the skin throughout life under steady-state conditions. Nat Immunol 2002;3:1135-41.

25 Romani N, Holzmann S, Tripp CH, Koch F, Stoitzner P. Langerhans cellsdendritic cells of the epidermis. APMIS 2003;111:725-40.

26 Valladeau J, Ravel O, Dezutter-Dambuyant C, Moore K, Kleijmeer M, Liu Y, et al. Langerin, a novel C-type lectin specific to Langerhans cells, is an endocytic receptor that induces the formation of Birbeck granules. Immunity $2000 ; 12: 71-81$

27 Hemmi H, Yoshino M, Yamazaki $H$, Naito M, lyoda T, Omatsu Y, et al. Skin antigens in the steady state are trafficked to regional lymph nodes by transforming growth factor-betal-dependent cells. Int Immunol $2001 ; 13: 695-704$.

28 de Saint-Vis B, Fugier-Vivier I, Massacrier C, Gaillard C, Vanbervliet B, AitYahia $S$, et al. The cytokine profile expressed by human dendritic cells is dependent on cell subtype and mode of activation. J Immunol 1998; 160:1666-76.

29 Bouloc A, Cavani A, Katz SI. Contact hypersensitivity in MHC class II-deficient mice depends on CD8 T lymphocytes primed by immunostimulating Langerhans cells. J Invest Dermatol 1998;111:44-9.

30 Janssens AS, Lashley EE, Out-Luiting CJ, Willemze R, Pavel S, de Gruij FR. UVB-induced leucocyte trafficking in the epidermis of photosensitive lupus erythematosus patients: normal depletion of Langerhans cells. Exp Dermatol 2005; 14:138-42.
31 Mori M, Pimpinelli N, Romagnoli P, Bernacchi E, Fabbri P, Giannotti B. Dendritic cells in cutaneous lupus erythematosus: a clue to the pathogenesis of lesions. Histopathology 1994;24:311-21.

32 Sallusto F, Lanzavecchia A. Efficient presentation of soluble antigen by cultured human dendritic cells is maintained by granulocyte/macrophage colony-stimulating factor plus interleukin 4 and downregulated by tumor necrosis factor alpha. J Exp Med 1994;179:1109-18.

33 Willmann K. Flow-cytometric immune function methodology for human peripheral blood dendritic cells. Methods Mol Biol 2003;215:41-57.

34 Willmann K, Dunne JF. A flow cytometric immune function assay for human peripheral blood dendritic cells. J Leukoc Biol 2000;67:536-44.

35 Gill MA, Blanco P, Arce E, Pascual V, Banchereau J, Palucka AK. Blood dendritic cells and DC-poietins in systemic lupus erythematosus. Hum Immunol 2002;63: 1172-80.

36 Siegal FP, Kadowaki N, Shodell M, Fitzgerald-Bocarsly PA, Shah K, Ho S, et al. The nature of the principal type 1 interferon-producing cells in human blood. Science 1999;284:1835-7.

37 Fritzler MJ. Clinical relevance of autoantibodies in systemic rheumatic diseases. Mol Biol Rep 1996;23:133-45.

38 Cederblad B, Blomberg S, Vallin H, Perers A, Alm GV, L Ronnblom. Patients with systemic lupus erythematosus have reduced numbers of circulating natural interferon-alpha-producing cells. J Autoimmun 1998;1 1:465-70.

39 Bennett L, Palucka AK, Arce E, Cantrell V, Borvak J, Banchereau J, et al. Interferon and granulopoiesis signatures in systemic lupus erythematosus blood. J Exp Med 2003;197:71 1-23.

40 Crow MK, Kirou KA. Interferon-alpha in systemic lupus erythematosus. Curr Opin Rheumatol 2004; 16:541-7.

41 Baechler EC, Gregersen PK, Behrens TW. The emerging role of interferon in human systemic lupus erythematosus. Curr Opin Immunol 2004; 16:801-7.

42 Ronnblom L, Alm GV. A pivotal role for the natural interferon alphaproducing cells (plasmacytoid dendritic cells) in the pathogenesis of lupus. $J$ Exp Med 2001;194:F59-63.

43 Lovgren T, Eloranta ML, Bave U, Alm GV, Ronnblom L. Induction of interferonalpha production in plasmacytoid dendritic cells by immune complexes containing nucleic acid released by necrotic or late apoptotic cells and lupus lgG. Arthritis Rheum 2004;50:1861-72.

44 Ronnblom L, Eloranta ML, Alm GV. Role of natural interferon-alpha producing cells (plasmacytoid dendritic cells) in autoimmunity. Autoimmunity 2003:36:463-72.

45 Ronnblom L, Alm GV. The natural interferon-alpha producing cells in systemic lupus erythematosus. Hum Immunol 2002;63:1181-93.

46 Vallin H, Blomberg S, Alm GV, Cederblad B, Ronnblom L. Patients with systemic lupus erythematosus (SLE) have a circulating inducer of interferonalpha (IFN-alpha) production acting on leucocytes resembling immature dendritic cells. Clin Exp Immunol 1999;115:196-202.

47 Mehling A, Loser K, Varga G, Metze D, Luger TA, Schwarz T, et al. Overexpression of CD40 ligand in murine epidermis results in chronic skin inflammation and systemic autoimmunity. J Exp Med 2001;194:615-28.

48 Bondanza A, Zimmermann VS, Dell'Antonio G, Dal Cin E, Capobianco A, Sabbadini $M G$, et al. Cutting edge: dissociation between autoimmune response and clinical disease after vaccination with dendritic cells. J. Immunol 2003;170:24-7.

49 Georgiev M, Agle LM, Chu JL, Elkon KB, Ashany D. Mature dendritic cells readily break tolerance in normal mice but do not lead to disease expression. Arthritis Rheum 2005;52:225-38.

50 Shodell M, Shah K, Siegal FP. Circulating human plasmacytoid dendritic cells are highly sensitive to corticosteroid administration. Lupus 2003;12:222-30.

51 Shodell M, Siegal FP. Corticosteroids depress IFN-alpha-producing plasmacytoid dendritic cells in human blood. J Allergy Clin Immunol 2001; 108:446-8.

52 Piemonti L, Monti $\mathrm{P}$, Allavena $\mathrm{P}$, Sironi $\mathrm{M}$, Soldini $\mathrm{L}$, Leone BE, et al. Glucocorticoids affect human dendritic cell differentiation and maturation. J Immunol 1999; 162:6473-81

53 Matasic R, Dietz AB, Vuk-Pavlovic S. Dexamethasone inhibits dendritic cell maturation by redirecting differentiation of a subset of cells. J Leukoc Biol 1999:66:909-14

54 Woltman AM, de Fijter JW, Kamerling SW, Paul LC, Daha MR, van Kooten C. The effect of calcineurin inhibitors and corticosteroids on the differentiation of human dendritic cells. Eur J Immunol 2000;30:1807-12.

55 Woltman AM, Massacrier C, de Fijter JW, Caux C, van Kooten C. Corticosteroids prevent generation of CD34+-derived dermal dendritic cells but do not inhibit Langerhans cell development. J Immunol 2002;168:6181-8.

56 Moser M, De Smedt T, Sornasse T, Tielemans F, Chentoufi AA, Muraille E, et al. Glucocorticoids down-regulate dendritic cell function in vitro and in vivo. Eur J Immunol 1995;25:2818-24.

57 Vulcano M, Struyf S, Scapini P, Cassatella M, Bernasconi S, Bonecchi R, et al. Unique regulation of CCL18 production by maturing dendritic cells. J Immunol 2003:170:3843-9.

58 Fox R. Anti-malarial drugs: possible mechanisms of action in autoimmune disease and prospects for drug development. Lupus 1996;5(Suppl 1):S4-10.

59 Mehling A, Grabbe S, Voskort M, Schwarz T, Luger TA, Beissert S. Mycophenolate mofetil impairs the maturation and function of murine dendritic cells. J Immunol 2000;165:2374-81.

60 Cavassani KA, Aliberti JC, Dias AR, Silva JS, Ferreira BR. Tick saliva inhibits differentiation, maturation and function of murine bone-marrow-derived dendritic cells. Immunology 2005; 114:235-45.

61 Veldman CM, Cantorna MT, DeLuca HF. Expression of 1,25-dihydroxyvitamin $D(3)$ receptor in the immune system. Arch Biochem Biophys 2000;374:334-8.

62 Bhalla AK, Amento EP, Serog B, Glimcher LH. 1,25-Dihydroxyvitamin D3 inhibits antigen-induced T cell activation. J Immunol 1984;133:1748-54. 
63 Piemonti L, Monti P, Sironi M, Fraticelli P, Leone BE, Dal Cin E, et al. Vitamin D3 affects differentiation, maturation, and function of human monocytederived dendritic cells. J Immunol 2000;164:4443-51.

64 Gauzzi MC, Purificato C, Donato K, Jin Y, Wang L, Daniel KC, et al. Suppressive effect of lalpha,25-dihydroxyvitamin D3 on type I IFN-mediated monocyte differentiation into dendritic cells: impairment of functional activities and chemotaxis. J Immunol 2005; 174:270-6.

65 Canning MO, Grotenhuis K, de Wit H, Ruwhof C, Drexhage HA. 1-alpha, 25Dihydroxyvitamin D3 $(1,25(\mathrm{OH})(2) \mathrm{D}(3))$ hampers the maturation of fully active immature dendritic cells from monocytes. Eur J Endocrinol 2001;145:351-7.

66 Griffin MD, Lutz W, Phan VA, Bachman LA, McKean DJ, Kumar R. Dendritic cell modulation by lalpha, 25 dihydroxyvitamin D3 and its analogs: a vitamin $D$ receptor-dependent pathway that promotes a persistent state of immaturity in vitro and in vivo. Proc Natl Acad Sci U S A 2001;98:6800-5.

67 Gregori S, Casorati M, Amuchastegui S, Smiroldo S, Davalli AM, Adorini L. Regulatory T cells induced by 1 alpha,25-dihydroxyvitamin D3 and mycophenolate mofetil treatment mediate transplantation tolerance. J Immunol 2001;167:1945-53.

68 van Halteren AG, Tysma OM, van Etten E, Mathieu C, Roep BO. Ialpha,25dihydroxyvitamin D3 or analogue treated dendritic cells modulate human autoreactive T cells via the selective induction of apoptosis. J Autoimmun 2004;23:233-9.
69 Huisman AM, White KP, Algra A, Harth M, Vieth R, Jacobs JW, et al. Vitamin $D$ levels in women with systemic lupus erythematosus and fibromyalgia. J Rheumatol 2001;28:2535-9.

70 O'Regan S, Chesney RW, Hamstra A, Eisman JA, O'Gorman AM, Deluca HF. Reduced serum 1,25-(OH)2 vitamin D3 levels in prednisone-treated adolescents with systemic lupus erythematosus. Acta Paediatr Scand 1979;68:109-11

71 Barnes TC, Bucknall RC. Vitamin D deficiency in a patient with systemic lupus erythematosus. Rheumatology (Oxford) 2004;43:393-4.

72 Glerup H, Mikkelsen K, Poulsen L, Hass E, Overbeck S, Thomsen J, et al. Commonly recommended daily intake of vitamin $D$ is not sufficient if sunlight exposure is limited. J Intern Med 2000;247:260-8.

73 Carre M, Ayigbede O, Miravet L, Rasmussen H. The effect of Prednisolone upon the metabolism and action of 25-hydroxy-and 1,25-dihydroxyvitamin D3. Proc Natl Acad Sci U S A 1974;71:2996-3000.

74 Redlich K, Ziegler S, Kiener HP, Spitzauer S, Stohlawetz P, Bernecker P, et al. Bone mineral density and biochemical parameters of bone metabolism in female patients with systemic lupus erythematosus. Ann Rheum Dis 2000;59:308-10.

75 Fox RI, Kang HI. Mechanism of action of antimalarial drugs: inhibition of antigen processing and presentation. Lupus 1993;2(Suppl 1):S9-12.

76 Mehling A, Beissert S. Dendritic cells under investigation in autoimmune disease. Crit Rev Biochem Mol Biol 2003;38:1-21. 